\title{
BOSAN DENGAN RAMBUT HITAM: \\ KAJIAN BUDAYA TENTANG TREN MEWARNAI RAMBUT DI KECAMATAN KOTA KUALA SIMPANG KABUPATEN ACEH TAMIANG
}

\author{
Eli Suprida \\ Program Studi Antropologi, Universitas Malikussaleh Lhokseumawe \\ Aceh-Indonesia
}

\begin{abstract}
Abstrak: Penelitian ini dilakukan di Kecamatan Kota Kuala Simpang Kabupaten Aceh Tamiang, dengan judul "Bosan Dengan Rambut Hitam" (Tren Mewarnai Rambut di Kota Kuala Simpang Kabupaten Aceh Tamiang). Teknik pengumpulan data yang digunakan dalam penelitian adalah deskriptif analisis dengan pendekatan kualitatif, untuk menggali data yang lebih akurat, serta penulis juga menggunakan teknik pengumpulan data melalui observasi, wawancara, mendalam, dan dokumentasi. Dari penelitian menunjukkan bahwa masyarakat mewarnai rambutnya dikarenakan mengikuti tren mewarnai rambut yang sedang berkembang saat ini. Melihat persoalan ini, Kebiasaan mewarnai rambut pada dasarnya tidak tumbuh pada hari ini, Keinginan untuk mewarnai rambut memang sudah berkembang sejak zaman Mesir Purba. Tak hanya itu, pemilihan kosmetika harus senantiasa didasarkan kepada kondisi rambut dan tujuan yang hendak dicapai. mimikri adalah suatu hasrat dari subjek yang berbeda menjadi subjek yang lain yang hampir sama, tetapi tidak sepenuhnya (as subject of a difference, that is almost the same, but not quite). Amerikanisasi telah menjadi salah satu aspek sejumlah ketakutan dan kecemasan umum atas semakin besarnya kapasitas kaum muda dan kelas pekerja untuk berpartisipasi dalam masyarakat konsumen yang lahir secara perlahan-lahan. Dampak amerikanisasi tidak luput dari peranan media massa yang berhasil merekontruksi jati diri mereka.
\end{abstract}

Kata Kunci: pewarnaan rambut, Budaya Mimikri, Budaya Massa 


\section{A. Pendahuluan}

Manusia sebagai makhluk Individu memiliki unsur jasmani dan rohani, unsur fisik dan psikis, unsur raga dan jiwa.Seseorang di katakan sebagai manusia individu manakala unsur-unsur tersebut menyatu dalam dirinya.Setiap manusia memiliki keunikan atau ciri khas. Tersendiri, tidak ada manusia yang persis sama. Dari sekian banyak manusia, ternyata masing-masing memiliki keunikan tersendiri.Ciri-ciri seorang individu tidak hanya mudah di kenali lewat fisik atau biologisnya. Sifat, karakter, perangai, atau gaya dan selera orang juga berbedabeda (Elly, dkk, 2008).

Dewasa ini, globalisasi berkaitan erat dengan modernisasi. Hal ini dikarenakan proses globalisasi yang terjadi dipengaruhi oleh proses kemajuan pengetahuan dan teknologi. Proses kemajuan pengetahuan dan teknologi tersebut adalah bagian daripada modernisasi. Dari sisi kebudayaan, tidak dipungkiri globalisasi dan modernisasi mempengaruhi atau merubah pola kehidupan bermasyarakat atau tatanan kehidupan sosial masyarakat yang mengalaminya. Hal ini dikarenakan adanya penyerapan dan pencampuran budaya dari masing-masing negara yang bersangkutan. Perubahan pola kehidupan masyarakat yang terjadi, menghasilkan pandangan-pandangan kehidupan yang berbeda pula.

Pandangan hidup artinya pendapat atau pertimbangan yang dijadikan pegangan, pedoman, arahan petunjuk hidup di dunia. Pendapat atau pertimbangan itu merupakan hasil pemikiran masyarakat yang mengalami perubahan sosial tersebut. Melalui globalisasi dan juga modernisasi, manusia dalam kaitannya dengan pandangan hidup memandang segala sesuatu dengan sisi pandangan yang berbeda dan lebih rasional.

Pada umumnya masyarakat Indonesia memiliki bentuk fisik yang memiliki kesamaan misalnya saja warna rambut berwarna hitam. Namum belakangan ini semakin banyak yang merubah warna rambutnya dikarenakan tren mewarnai rambut dikalangan selebritis Indonesia, tak hanya di kota-kota besar, trend mewarnai rambut sudah sampai ke kota kecil hingga ke desa-desa, khususnya di Kabupaten Aceh Tamiang. 
Kabupaten Aceh Tamiang adalah salah satu kabupaten di Provinsi Aceh, Indonesia. Kabupaten ini berada diujung aceh yang berbatasan langsung dengan provinsi Sumatra Utara, Kabupaten ini berada di jalur Timur Sumatera yang strategis dan hanya berjarak lebih kurang $250 \mathrm{~km}$ dari Kota Medan sehingga akses serta harga barang di kawasan ini relatif lebih murah dari pada daerah Aceh lainnya, hal inilah yang menjadi salah satu faktor pendorong gaya hidup masyarakat Kabupaten Aceh Tamiang yang jauh dari kata daerah Aceh. Pasalnya Aceh sendiri identik dengan peraturan syari'at Islam yang ketat, peraturan ini tidak berlaku di Kabupaten Aceh Tamiang. Penerapan syari'at Islam di Kabupaten Aceh Tamiang tidak berjalan dengan baik. Pada kenyataannya, peraturan penggunaan jilbab yang diwajibkan pada kalangan wanita tidak mengikuti syari'at Islam yang di terapkan pada daerah-daerah Aceh lainnya. Masyarakat Kabupaten Aceh Tamiang masih banyak yang tidak menggunakan hijab, hal ini juga yang mendorong semakin banyaknya gaya merubah bentuk rambut, hingga mewarnai rambut.

Kebiasaan mewarnai rambut pada dasarnya tidak tumbuh pada hari ini, Keinginan untuk mewarnai rambut memang sudah berkembang sejak zaman Mesir Purba. Bahkan ramuan yang di jadikan zat warna berasal dari alam seperti tumbuh- tumbuhan dengan tujuan untuk memperbaiki penampilan. Salah satu aspek yang mempengaruhi penampilan adalah rambut, posisi yang berada didepan menjadikan rambut sebagai bagian yang pertama kali dilihat oleh orang lain serta menjadikan rambut sebagai pembeda dan ciri khas seseorang.

Warna rambut ditentukan oleh pigmen melanin di dalam rambut yang ada dalam lapisan korteks. Bahan asal pigmen melanin adalah melanosit yang berada dalam umbi rambut. Melanosit adalah sel-sel yang menghasilkan pigmen (zat warna) yang menyebabkan rambut asli dapat memiliki bermacam-macam warna. Bila sudah mencapai usia lanjut, warna rambut berubah menjadi putih, dan ini sering kurang disukai keberadaannya. Rambut menjadi putih dapat disebabkan 
karena hilangnya aktivitas enzim dalam sel pigmen dan bisa juga akibat faktor keturunan. ${ }^{1}$

Warna rambut dapat diubah-ubah secara buatan dengan menggunakan cat rambut, di Indonesia disebut juga dengan semir rambut, yaitu mengecat rambut putih (uban) agar tetap nampak hitam. Warna rambut pada manusia bermacam-macam, ada yang berwarna hitam, merah kecokelatan, cokelat, keemasan atau pirang dan sebagainya. Sediaan pewarna rambut adalah kosmetika yang digunakan dalam tata rias rambut untuk mewarnai rambut, baik untuk mengembalikan warna rambut asli atau mengubah warna rambut asli menjadi warna baru (Latirah, dkk, 2005).

Namun belakangan ini, pewarnaan rambut semakin digemari oleh banyak kalangan dari remaja hingga dewasa baik wanita maupun pria di Kota Kuala Simpang. Fenomena kehidupan sosial kebudayaan dan gerak tubuh keseharian selalu berkaitan erat dengan media yang memberikan berbagai informasi kehidupan sosial lainnya. Media memiliki posisi sebagai penyampai sebuah pesan yang dikirimkan kepada khalayak ramai atau masyarakat. Jaringan media masa mempunyai kekuatan untuk merubah identitas individu seiring dengan munculnya hubungan lintas batas Negara. Tidak hanya media yang menjadi faktor perubahan sosial kebudayaan suatu masyarakat. Akan tetapi pada prakteknya lingkunganlah yang berperan penting menjadikan suatu perubahan sosial pada masyarakat. Hal ini yang membuat penulis tertarik untuk mengangkat masalah ini kedalam sebuah sebuah kajian.

\section{B. Metode Penelitian}

Penelitian ini menggunakan metode kualitatif, yaitu penelitian dengan mengumpulkan data lapangan yang kemudian dibahas dan dianalisis dengan mengacu pada landasan teoritis (Meleong, 2016). Pendekatan yang penulis lakukan adalah Budaya Massa dan Amerikanisasi, Modernisasi dan Budaya Mimikri.

\footnotetext{
1 Dra. Anayanti Arianto, M. Si. Apt: Pewarna Rambut, Universitas Sumatra Utara Ocw.usu.ac.id>8170000114-kosmetologi
} 
Penelitian ini dilakukan di Kota Kuala Simpang Kabupaten Aceh Tamiang yang merupakan sebuah kecamatan dengan pusat perdagangan yang dikunjungi oleh setiap masyarakat yang berada di sekitar Kota Kuala Simpang, hingga masyarakat yang berada di luar kecamatan itu sendiri.

Lokasi penelitian ini juga sangat berperan dalam menjawab masalah dan tujuan dari penelitian ini, mengingat sebuah kota terbentuk dan berkembang secara bertahap sesuai dengan peningkatan kegiatan manusia, dimana manusia sebagai pelaku kegiatan saling berinteraksi dalam kehidupannya. Dalam hal ini kota terbentuk sebagai fungsi dari aktifitas manusia yang luas dan komplek, yang terakumulasi dari waktu ke waktu. Pusat kota semakin tinggi intensitasnya dan semakin beragam pula fungsi-fungsi kegiatannya, sedangkan kegiatan yang ada dapat berupa suatu interaksi ekonomi, atau suatu bentuk organisasi sosial atau keagamaan. Ketika malam tiba Kota Kuala Simpang berubah menjadi tempat jajanan pingir jalan, seperti berdagang minuan TST (teh susu telur) yang telah digemari oleh banyak kalangan dari remaja hingga dewasa, lelaki hingga wanita, tak hanya itu warung-warung kopi yang sudah menjamur di Kota Kuala Simpang menjadi tujuan selanjutnya untuk berinteraksi dan sebagai gaya hidup modern. Disinilah terlihat berbagai macam gaya induvidu dan kelompok. Oleh karena itu, penulis bermaksud untuk melakukan penelitian dengan judul "Bosan Dengan Rambut Hitam" (Kajian Budaya Tentang Tren Mewarnai Rambut), alasan penulis memilih Kota Kuala Simpang menjadi lokasi penelitian dikarenkan beragam fungsi-fungsi kegiatan dan menjadi tempat interaksi sosial dengan aktifitas masyarakatnya yang kompleks.

\section{Pembahasan}

Budaya Massa dan Amerikanisasi sebagai acuan salam melihat tren mewarnai rambut di Kecamatan Kota Kuala Simpang. Dalam Budaya Massa dan Amerikanisasi menjelaskan budaya massa terbentuk dari budaya kerumunan, lahir dari banyaknya massa yang menikmati produk budaya karena pengaruh dari periklanan, televisi, dan radio. Secara sederhana dapat dikatan bahwa budaya massa adalah budaya populer yang dihasilkan melalui teknik-teknik industrial produksi massal dan dipasarkan untuk mendapatkan keuntungan kepada khalayak 
konsumen massa. Budaya massa ada kaitanya dengan proses Amerikanisasi. Alasannya adalah budaya populer Amerika dipandang membungkus semua kesalahan dalam kaitannya dengan budaya massa. Karena budaya massa dianggap muncul dari produksi massal dan konsumsi komuditas kultural, maka relatif mudah untuk mengidentifikasi Amerika sebagai pusat budaya massa karena masyarakat kapitalis yang erat kaitannya dengan proses- proses tersebut. Amerikanisasi itu sebuah gerakan budaya western yang lahir dari produk budaya yang bias disaksikan lewat televisi, film, radio, dan semacam ajang MTV, dan filmfilm Hollywood. Pengaruh Amerikanisasi sangat kuat mempengaruhi massa yang menonton dan menikmatinya sehingga infiltrasi budaya Amerika itu masuk ke dalam jiwa penontonnya, sehingga penonton dapat mengikutinya.

Masyarakat yang menjadi mangsanya telah memiliki persepsi berlainan terhadap produk yang ditawarkan, hal ini dipengaruhi dari tingkat pendidikan serta pengalaman seseorang. Sebuah iklan, televisi, dan radio dinilai mampu menggiring pikiran pemirsa untuk mau mengikuti apa yang divisualisasikan dengan hebatnya, hingga seseorang terbius oleh pesan yang ada dibalik kemasan produk citraannya. Tidak sedikit masyarakat yang percaya dengan produk-produk citraan hasil rekontruksi dari iklan, televisi, dan radio, hingga masyarakat mau membeli demi semata-mata menaikkan citra dirinya, seperti yang dilakukan oleh masyarakat Kecamatan Kota Kuala Simpang yang merubah warna rambutnya, agar menyerupai dan mengeikuti yang mereka lihat di televisi. Kenyataan ini mengatakan, bila suatu produk kapitalis menyerang suatu status sosial masyarakat tertentu, maka budaya sosial lama semakin tergeser dengan budaya baru yang ditawarkan, karena pada dasarnya ketika kemauan atau nafsu suatu manusia timbul dan memuncak dikepala, maka secara cepat itu pula reaksi mereka akan memenuhi keinginan tesebut. Pada dasarnya prinsip dari iklan, televisi, dan radio adalah menyampaikan produk baru sambil membawa paham serta budaya baru pula, sebagai pencerminan dari penemu teknologi hingga menciptakan peradaban baru dan lama kelamaan akan berkembang di masyarakat. Salah satu contoh produk pewarnaan rambut melalui iklan televisi 
adalah Bunga Citra Lestari menjadi target marketing dari produk pewarna NYU.

\section{Tubuh Sebagai Eksterioritas}

Pada titik ini tubuh lebih dilihat sebagai eksterioritas, sebagai kecendrungan- kecendrungan liar yang bisa mengancam stabilitas tatanan sosial, keberadaban kehidupan publik, dan kewarasan penalaran. Dikemudian harinya teknik pengusaan tubuh ini memang lebih berkembang lagi bersama dengan evolusi teknik regulasi pada tingkat intitusi pemerintahan (cara menghukum, pola kemiliteran), pendidikan (disiplin), medis (berbagai pengobatan, tuntutan diet dan latihan kebugaran), dan terutama perdagangan (di mana citra diri dijajakan sebagai citraan-citraan tubuh badani). Maka dengan sendirinya fokus pun bergeser dari aspek interioritas tubuh pada aspek eksterioritasnya.

Situasi Perang Dunia II membawa pola perkembangan kapitalisme, yakni terjadi percanggihan dan perluasan melalui sistem kredit dan konsumsi massa. Dan disinilah terjadi apa yang di sebut Daniel Bell sebagai kontradiksi budaya dalam kapitalisme. Salah satu kontradiski utama misalnya adalah : disatu pihak pola produksi yang rasional menuntut tubuh untuk di disiplinkan, di atur dan ber"akses" di tempat kerja, dipihak lain pola konsumsi mengkondisikan agar di rumah dan dalam aktivitas di luar kerja tubuh dimanjakan untuk mengkonsumsi apa pun pada tingkat paling hedonistik, rakus dan serakah. Pada tatanan konsumsi ini tubuh semakin dialami sebagai wahana untuk kesenangan, untuk dinikmati, untuk bermain, sekaligus untuk ditonton dan "dibeli” sebagai komuditas. Makin mampu tubuh memperlihatkan citra ideal kemudaan, kebugaran, vitalitas, dan keindahan, makin tinggi "nilai tukar" atau nilai komuditasnya. Bila dalam model religious tradisional tubuh dikekang dan didisiplinkan agar manusia lebih mampu memasuki interioritasnya yang lebih dalam, dalam model masyarakat konsumsi perilaku dan bentuk tampilan tubuh direkayasa agar eksterioritasnya lebih meningkat dan memikat. Etika perlahan bertranformasi menjadi estetika. Citra diri pun menjadi identik dengan citra tubuh, bila dalam religiositas tradisional tubuh ditaklukkan oleh jiwa, dalam masyarakat konsumsi sebaliknya, jiwa ditaklukkan oleh tubuh (Sugiharto, 2000). 
Kenyataan diatas itu serentak menunjukkan paradoks modernitas, sebab konon suatu ciri utama modernitas yang matang adalah tampilnya kedirian yang refleksif (reflextive self). Begitulah sekurang-kurangnya yang diyakini oleh Antony Giddens dan Urich Beck. Dalam masyarakat modern konon "diri" itu dibayangkan sebagai suatu proyek, sesuatu yang harus direkontruksikan dan diadaptasikan terus- menerus sesuai dengan siklus hidup. Tapi, karena ternyata tubuh pun merupakn proyek yang bisa direkontruksi, dan de facto perhatian terhadap tubuh lebih dominan dari pada terhadap refeksivitas, hingga menggilas kemampuan kritis dan membungkam rasionalitas, maka konsep ke"diri"-an itu kini jadi taksa (ambigu).

\section{Tren Mewarnai Rambut di Kalangan Masyarakat Di Kecamatan Kota Kuala Simpang}

Masyarakat memiliki keinginan untuk selalu merubah dan mengikuti halhal yang baru. Berbagai barang yang menjadi simbol modernitas, hal itu berakibat pada gaya hidup masyarakat yang mana mengkonsumsi berbagai produk dan benda atau barang yang disebut modern. Salah satu cara mengukur gaya hidup yang modern di tandai dengan gaya berpakain dan gaya rambut. Masyarakat selalu mengubah penampilan mereka sesuai dengan perkembangan zaman. Menurut mereka penampilan adalah nomor satu. Mewarnai rambut bukanlah hal asing lagi bagi masyarakat Kecamatan Kota Kuala Simpang, bahkan tak hanya remaja saja yang melakukan pengecatan rambut, melainkan orang dewasa dari laki-laki hingga perempuan di Kecamatan Kota Kuala Simpang. Pada zaman sekarang pengecatan rambut tidak hanya untuk menutupi uban saja, melainkan untuk menunjang penampilan agar terlihat lebih modis dan trendi. Mengecat rambut tidak hanya dilakukan sekali, mereka melakukan berkali-kali sesuai dengan keinginan dan tren yang sedang beredar di masyarakat. Perhatikan tabel dibawah ini:

Tabel 1

Gambaran Penelitian Tren gaya rambut di Kecamatan Kota Kuala Simpang

\begin{tabular}{|c|c|c|c|c|c|}
\hline \multirow{2}{*}{ No } & \multirow{2}{*}{ Nama } & \multicolumn{2}{|c|}{ Jenis Kelamin } & Umur & Motif Mewarnai \\
\hline & & Laki- & Perem & (Thn) & Rambut \\
\hline
\end{tabular}




\begin{tabular}{|c|l|l|l|l|l|} 
& & laki & puan & & \\
\hline 1. & Raygay Singgih & L & & 14 & Ikut/ajakan teman \\
\hline 2 & Wulan Agus Wijayanti & & $\mathrm{P}$ & 22 & Mengikuti tren \\
\hline 3 & Pemuda Unik Namun & $\mathrm{L}$ & & - & Mengikuti tren \\
& Kreatif (Punk) & & & & \\
\hline
\end{tabular}

Sumber: Hasil Analisis Penelitian, 2019

Meskipun pewarnaan rambut belum menjadi bagian gaya hidup kebanyakan masyarakat, faktanya semakin banyak masyarakat yang senang mewarnai rambut, khususnya di Kecamatan Kota Kuala Simpang. Tampil beda memang menjadi tujuan utama pewarnaan rambut. Dengan beragam pilihan warna rambut, masyarakat punya lebih banyak pilihan gaya penampilan. Tak sedikit masyarakat melakukan pengecatan rambut sendiri, dengan alasan lebih murah dari pada melakukan pengecatan di salon yang harganya berkisar 100-300 ribu tergantung pilihan produk dan panjang rambut. Pendapat masyarakat tentang tren mewarnai rambut di Kecamata Kota Kuala Simpang, Yuli Rahmawati Dan Vera Andriani Salah Satu Maysrakat Di Kecamatan Kota Kuala Simpang

“...mewarnai rambut tidak lagi menjadi hal yang aneh, karena tidak sedikit yang mewarnai rambut. Melihat mereka mewarnai rambut lebih terlihat cantik/ganteng serta lebih menarik. Ikut mewarnai rambut juga diajak oleh teman-teman agar tidak terlihat ketinggalan zaman dan lebih terlihat trendi..."(wawancara 11 juni 2017)

Dari hasil wawancara di atas kita ketahui bahwa tidak semua masyarakat tidak menyukai mereka yang mengikuti tren mewarnai rambut. Pada kenyataannya di masyarakat beredar pula persipsi bahwa wanita yang mengikiti tren mewarnai rambut sebagai wanita tidak baik "Nakal", sedangkan bagi lakilaki persepsi ini tidak berlaku. Hanya saja lelaki yang mengikuti tren mewarna rambut termasuk kedalam golongan anak jalan. Persepsi bagi wanita yang mewarnai rambut sangat tidak masuk akal, antara mewarnai rambut dengan kelakuan tidak ada hubungannya. Menurut penulis persepsi ini ada kaitannya 
dengan sejarah di zaman Kekaisaran Romawi bahwa para wanita penjaja seks yang salam lingkungan.

Kekaisaran diberi status legal, dilindungi, dan dipungut pajak, diharuskan mewarnai kuning rambutnya sebagai identitas profesi. Ratu Messalina (circa 48 SM) istri dari Kaisar Claudius I (10-54 SM) yang terkenal akan gairah seksualnya, menggunkan wig berwarna kuning agar dapat bebas pergi ke lorong-lorong kota Roma guna mendapatkan pasangan berkencan (Latirah, 2002). Pada faktanya saat ini, persepsi wanita yang mewarnai rambutnya disebut sebagai perempuan nakal, karena sebagian dari mereka berprofesi sebagai biduan dari panggungkepanggung, yang kita jumpai saat pesta rakyat atau pesta pernikahan. Disini, biduan dianggap "nakal” baik laki-laki maupun perempuan. Tak hanya biduan saja, wanita yang dijumpai pada jam $11 \mathrm{mlm}$ keatas dapat dikatan sebagai wanita tidak baik "nakal" di tunjang juga dengan cara berpakaian. Hal ini lah yang menjadikan persepsi tidak baik oleh masyarakat. Padahal tujuan mewarnai rambut hanya untuk mengubah penampilan agar terlihat lebih menarik dan mengikuti tren yang sedang berlangsung saat ini. Pendapat lain di ungkapkan beberapa orang yang sedang duduk di salah satu warung TST di Kecamatan Kota Kuala Simpang.

\section{Kesimpulan}

Kebiasaan mewarnai rambut pada dasarnya tidak tumbuh pada hari ini, Keinginan untuk mewarnai rambut memang sudah berkembang sejak zaman Mesir Purba. Bahkan ramuan yang dijadikan zat warna berasal dari alam seperti tumbuhtumbuhan dengan tujuan untuk memperbaiki penampilan. Pewarnaan terbagi atas pewarna nabati (vegetable dry), pewarna logam (metallic dye), pewarna campuran, pewarna sintetik organik (synthetic organic tint). Terdapat 3 proses pewarnaan menambah warna (hair tinting), pemudaan warna (hair light tening), dan penghilang warna (bleaching). Tren mewarnai rambut di Kecamatan Kota Kuala Simpang dilihat dari motif yang mendasari mereka merubah warna rambut, fenomena mewarnai rambut dalam konsep mimikri, budaya massa dan Amerikanisasi, dan pendapat masyarakat sekitar setelah mewarnai rambut. 
Aceh Anthropological Journal, Vol. 4, No. 1, hlm: 110-121, April 2020

Motif yang mendasari mereka merubah warna rambut yaitu di lihat dari 3 aspek yang pertama mengikuti tren mewarnai rambut, kedua ingin terlihat lebih menarik, dan ketiga ajakan teman atau melihat teman-teman mewarnai rambut. Pada prakteknya motif mereka mewarnai rambut tidak hanya itu saja, melainkan banyak aspek-aspek yang mendorong mewreka merubah warna rambut. Disini peneliti lebih terfokus melihat motif mereka mewarnai rambut ke dalam konsep budaya mimikri, budaya massa dan Amerikanisasi. 


\section{Daftar Pustaka}

Setiadi, Elly M. dkk, 2008. Ilmu Sosial dan Budaya Dasar. Jakarta: Prenada Media Group.

Moleong, Lexy J. 2016. Metode Penelitian Kualitatif. Bandung: PT. Remaja Rosdakarya

Statistik Kabupaten Aceh Tamiang dengan Bappeda Kabupaten Aceh Tamiang

Dra. Anayanti Arianto, M. Si. Apt: Pewarna Rambut, Universitas Sumatra Utara Ocw.usu.ac.id>8170000114-kosmetologi

Latirah,dkk, 2015. Pengembangan Pewarna Rambut dari Ekstrak Gambir dalam Sediaan Setengah Padat. Jurnal Ilmu Kefarmasian Indonesia, Universitas Pancasila. www.docs-engine.com

Sugiharto, Bambang, 2000. Menguak Tubuh. Kalam Jurnal Kebudayaan, Jakarta: Yayasan Kalam. 